\title{
A Task-based Approach to Materials Development
}

\author{
David Nunan
}

doi:10.7575/aiac.alls.v.1n.2p.135

\section{Summary}

The purpose of this chapter is to present a task-based approach to materials development. In the first part of the chapter, I sketch out the evolution of taskbased language teaching, drawing on a distinction between synthetic and analytical approaches to syllabus design first articulated by Wilkins (1976).

I then define the concept of 'task', and show how it relates to broader education considerations. In defining 'task', I draw a basic distinction between 'real-world' or 'target' tasks (those things people do with language in the world outside the classroom), and 'pedagogical' tasks, that is, tasks to engage learners in mastering the language in the classroom. Pedagogical tasks are subdivided into 'rehearsal' and 'activation' tasks. Also discussed in this section is the relationship between communicative language teaching and task-based language teaching. Drawing on the work of Littlewood (1981), I discuss the 'strong' and 'weak' interpretations of the two approaches.

The bulk of the chapter is then devoted to describing the practical steps involved in developing materials based on a task based approach. Firstly, I set out the steps involved in the overall course design process. I then illustrate the way in which 
this process can be used for creating a module of work. The chapter concludes with a brief discussion of some issues that need to be considered in implementing a task-based approach.

While my work as a materials designer and developer has been carried out in a foreign language context, the procedures described in this chapter are suitable for a wide variety of ESL and EFL contexts. The principles and procedures described and exemplified here can be used in writing textbooks and other materials for preadolescents, adolescents, and adults.

\section{Background}

The story of task-based language teaching reaches back to 1976. In that year, David Wilkins drew a basic distinction between synthetic and analytical approaches to language pedagogy. Wilkins argued that despite their differences all syllabuses and materials fitted into one of these two approaches.

Synthetic approaches to pedagogy are language centred. In other words, the starting point for such approaches is an analysis of the language to be taught. The language is broken down into its phonological, lexical and grammatical components, and these are taught separately, and piece by piece to the learner. Wilkins gave the label 'synthetic' to the approach because in order to use the language to communicate, the challenge for the learner is to reassemble, or synthesize the components. Grammar-translation, audiolingualism, and most of the 'designer' methods such as Total Physical Response (Asher, 1988) are basically synthetic in nature. 
Analytical approaches are learner-centred in the sense that they begin, not with an analysis of language, but with a consideration of learners and the purposes for which they are learning the language in the first place. In such approaches:

Prior analysis of the total language system into a set of discrete pieces of language that is a necessary precondition for the adoption of a synthetic approach is largely superfluous ... [Such approaches] are organized in terms of the purposes for which people are learning language and the kinds of language that are necessary to meet these purposes. (Wilkins, 1976, p. 13)

Any syllabus or set of materials that does not take as its point of departure the prior analysis of language systems is analytical in nature. These include taskbased, content-based, and text-based materials. They are called analytical because learners are presented with holistic chunks of language and are required to break these down, or to analyze them, into their component parts.

Within the literature, various definitions have been offered for 'task'. Long (1985, p. 89) provides a real-world or target task definition (so called because it describes what the learner will do with language in the world outside of the classroom).

[A task is] a piece of work undertaken for oneself or for others, freely or for some reward. Thus examples of tasks include painting a fence, dressing a child, filling out forms, buying a pair of shoes, making an airline reservation, borrowing a library book, taking a driving test, typing a letter, weighing a patient, sorting letters, making a hotel reservation, writing a cheque, finding a street destination, and helping someone across a road. In other words, by 'task' is meant the hundred and one things people do in everyday life, at work, at play and in between. 
Pedagogical tasks, on the other hand, describe what learners do in the classroom to activate and develop their language skills. Although these tasks are designed for the classroom, there should also be a connection, however tenuous, to corresponding real-world or target tasks. It is particularly important that the students are able to see a connection between the work they do in the classroom, and the world beyond the classroom. Here is a description, with examples, of pedagogical tasks.

$\ldots$ an activity or action which is carried out as the result of processing or understanding language (i.e. as a response). For example, drawing a map while listening to a tape, listening to an instruction and performing a command may be referred to as tasks. Tasks may or may not involve the production of language. A task usually requires the teacher to specify what will be regarded as successful completing of the task. The use of a variety of different kinds of tasks in language teaching is said to make language teaching more communicative... since it provides a purpose for a classroom activity which goes beyond the practice of language for its own sake. (Richards, Platt \& Weber, 1986, p. 289)

As you can see, pedagogical tasks are things that learners undertake in order to acquire language in instructional settings. Target tasks, on the other hand are things that people do in everyday life. For language learners, these also provide opportunities for language learning as well as language activation.

Skehan (1998) synthesizes the views of a number of writers, and suggests that pedagogical tasks exhibit five key characteristics:

- meaning is primary

- learners are not given other people's meanings to regurgitate

- there is some sort of relationship to comparable real world activities 
- task completion has some priority

- the assessment of the task is in terms of outcome

(See also Bygate, Skehan \& Swain, 2001; Willis \& Willis, 2001; Ellis, 2003).

In my book on TBLT (Nunan, 2004), I subdivide pedagogical tasks into rehearsal tasks and activation tasks. Rehearsal tasks, as the name implies, are designed to provide learners with an opportunity for the direct rehearsal in the classroom of a target type task. While not identical to a real world task, the relationship between the pedagogical task and its real world counterpart will be transparent. Here is an example of a real world task:

- Carry out an online search and find options for travelling from Singapore to Hong Kong during the Christmas break. Find out about available flights, identify the cheapest options, and find out which have hotel packages.

Activation tasks, on the other hand, have only an indirect relationship to the real world. Consider a spot-the-difference task in which learners working in pairs, have two versions of a picture. They have to describe their pictures to each other and identify a prespecified number of differences (e.g., Go For It $2^{\text {nd }}$ edition, level 2, pp. $124 \& 126$, Communicative activity 2). This task is not a rehearsal task. People do not as a rule sit around in cafes or bars playing 'guess what's in my picture'. The rationale for such tasks is that they will stimulate students to activate the language forms and functions they have been learning. (In the 
example above, these will include describing appearance and reporting actions as well as using predicative and attributive adjectives, prepositions and the present progressive tense.)

In one of the earliest book-length introductions to communicative language teaching, Littlewood (1981) drew a distinction between a 'strong' and a 'weak' interpretation of CLT. A similar distinction can be used in TBLT. Proponents of the strong interpretation argue that a focus on form is unnecessary for successful language acquisition (see, for example Krashen 1981, 1982). These proponents argue that a focus on language form is unnecessary, that the necessary and sufficient condition for successful acquisition for learners is to engage in communicative tasks. Proponents of a weak interpretation, on the other hand, acknowledge the need for such a focus. I subscribe to the weak interpretation, which allows room for a specific focus on form. There is growing evidence, particularly in EFL contexts, that learners who receive such a focus on form within a task-based curriculum acquire language more effectively than those who do not have such a focus (Swain, 1985; Doughty \& Williams, 1998).

In making his case for a weak interpretation of CLT, Littlewood argues that the following skills need to be mastered for successful second language acquisition. As one methodological realization of CLT, the points are also relevant to TBLT.

- The learner must attain as high a degree as possible of linguistic competence. That is, he must develop skill in manipulating the linguistic 
system, to the point where he can use it spontaneously and flexibly in order to express his intended message.

- The learner must distinguish between the forms he has mastered as part of his linguistic competence, and the communicative functions which they perform. In other words, items mastered as part of a linguistic system must also be understood as part of a communicative system.

- The learner must develop skills and strategies for using language to communicate meaning as effectively as possible in concrete situations. He must learn to use feedback to judge his success, and, if necessary, remedy failure by using different language.

- The learner must become aware of the social meaning of language forms. For many learners, this may not entail the ability to vary their own speech to suit different social circumstances, but rather the ability to use generally acceptable forms and avoid potential offensive ones. (Littlewood, 1981, p.6)

\section{Steps in the materials design process}

In this section, I will describe a set of procedures for task-based materials design. I will begin by setting out the steps to follow in developing a course before looking in detail at developing a module of work within that course.

\section{Course design}

Step 1 Create an inventory of target / real word tasks 
As I have already indicated, the first step in the design process is to create an inventory of target tasks. These should reflect the overall purposes of the learners for whom the materials are being designed. For example:

- General communication

- Tourism

- Business / workplace

- Further study

Here are some target tasks taken from a general communication course:

\begin{tabular}{|c|c|}
\hline Listening / speaking & Reading / writing \\
\hline Give directions from school to your home & Extract key informational brochures \\
\hline Invite friends over for a party & Scan newspaper articles for specific \\
\hline Study the 'to rent' section of a newspaper and & information \\
\hline decide on the most suitable place to rent. & Extract key information from a travel brochure \\
\hline Plan a school reunion & Complete an application to join a club \\
\hline Plan an orientation program for a group of & Write a letter to a host family \\
\hline exchange students & Write a letter of congratulations \\
\hline Give instructions on how to make a hamburger & Write a get well card \\
\hline Help another student plan a presentation & Complete a job application \\
\hline $\begin{array}{l}\text { Make arrangements to meet a friend later in the } \\
\text { week }\end{array}$ & Write an email apology \\
\hline
\end{tabular}

(Source: Adapted from Nunan, 2001)

\section{Step 2: Collect samples of authentic spoken and written texts}

The next step is to collect samples of spoken and written texts relating to the target tasks specified in Step 1. The easiest way to collect spoken language data is to get pairs or groups of native speakers / competent users of the language to do the tasks. Record them as they do the tasks, and then transcribe the interactions.

Step 3: Analyze the authentic data and identify linguistic exponents 
This step is somewhat controversial. In a 'strong' approach to TBLT, prior analysis of the language forms and functions underpinning a communicative task is unnecessary, as is the classroom presentation and practice of the forms and functions. As I said in the preceding section, in the 'weak' interpretation of TBLT, a focus on language form and function is a central part of the pedagogy. (Littlewood, 1981; Willis, 1996).

Most tasks require learners to use a range of language forms. Judgment is required in deciding which of these is to be the explicit focus of a unit of work. In making such judgments, it is useful to bear in mind Ellis's (2003) distinction between focused and unfocused tasks. An unfocused task is one in which the learners are able to use any linguistic resources at their disposal in order to complete the task. A focused task, on the other hand, is one in which a particular structure is required in order for a task to be completed.

These three major steps in the course design process provide the basis for developing modules of work. In the next section of the chapter, I describe one way in which this process can activated.

\section{Developing a module of work}

There are many ways in which principles of task-based learning can be exploited to develop a module of work. In this section I will illustrate one such way. Before embarking on this however, several important questions need to be considered. 
- To what extent will the materials provide an explicit focus on form, particularly on grammar and pronunciation?

- If there is to be an explicit focus on form, at what point in the instructional cycle will it appear? (That is, will learners be provided with an explicit focus on form at the beginning of the cycle, or at some point during the cycle?)

- Will learners be given an opportunity for controlled practice?

- To what extent will learners be given an opportunity to focus on the learning process and learning how to learn?

\section{Focus on form}

As I have already pointed out, a strong interpretation of TBLT eschews any explicit focus on form. However, the weak interpretation, which does advocate a focus on form, appears to be in the ascendancy these days. Studies reported in collections such as Doughty and Williams (1998) provide evidence that a focus on form is healthy for language development. (See also Ellis, 2003).

In the 'weak' interpretation of TBLT, the key question is not whether to introduce a focus on form, but when and how. Is it better to introduce the form, drill it, and then get learners to apply it in a communicative task which mirrors the audiolingual three Ps (Presentation - Practice - Production) methodology, or is it better to weave the form-focused exercises into the fabric of the lesson? 
My own preference is for the latter approach. Creating materials in which learners use the target language forms communicatively before explicitly laying bare the forms helps the learners to see the relationship between form and function. It helps them get the point. It also puts the language systems in their place. They exist, not as an end in themselves but as a means to an end - and that end is communication.

These comments on the place of grammar relate to integrated four-skills series. Supplementary materials, and single skills series for developing listening, or reading or conversation typically do not incorporate a focus on form. (For examples related to reading, see Anderson, 2006; for listening, see Nunan, 2003).

\section{Controlled practice}

Intensive repetitive practice of target language forms was the foundation on which audiolingualism was constructed. A key issue for designers of task-based materials is how to incorporate such controlled practice into materials that are built on an alternative view of pedagogy, that is, in which the point of departure for the development of materials is not a list of grammatical, lexical and phonological features, but an inventory of the kinds of things that learners will want to do with language.

In the approach that I am advocating in this chapter, while the point of departure for materials design is basically analytical - that is, the process begins with an inventory or target / real world tasks, there is also an explicit focus on the three linguistic subsystems of grammar, words and sounds (for an elaboration and 
discussion see Nunan, 2007). During the course of the materials development process, a synthetic syllabus also emerges. However, it is important to note that this syllabus emerges during the materials development process rather than being the point of departure for materials design. The end result, however, is a blend of an analytical and synthetic syllabus. With a little imagination and ingenuity, it is possible to create contexts and situations in which this can be done. Imaginative authors such as Ur (1988), Thornbury (2000) and others have a wealth of ideas for providing controlled practice within a communicative context.

\section{Learning how to learn}

A focus on the learning process, on learning how to learn and on learning strategy training has evolved along with TBLT, although TBLT and learner strategy training are not coterminous. It is possible to design task-based materials that do not have an explicit focus on strategies, and it is possible to incorporate strategy training into non-TBLT materials. The relationship between TBLT and strategy training developed as materials writers realised that all pedagogical tasks are underpinned by at least one strategy, and that making learners consciously aware of those strategies could lead to more effective language learning (Scarcella \& Oxford, 1992).

Another reason for incorporating a learning-how-to-learn dimension is that it helps to raise learner consciousness about the learning process in general. This is particularly important when introducing TBLT to learners who have been raised on a traditional pedagogical diet. These learners often fail to see the point of TBLT, and resist the approach on the grounds that "it isn't really language 
learning" because they are not memorizing grammar rules. Changing the way that they think about language and learning is an important part of maximizing the effectiveness of a task-based approach.

There are many ways of making learning strategies and processes explicit. The most straightforward is simply to tell the learners. This is the approach that I adopted in a task-based series I developed in the early 1990s. Next to the task, I added a sidebar highlighting in yellow the strategy underpinning the task. I left it up to the teacher to decide how to incorporate a strategy focus into his or her lesson.

Another way of encouraging a focus on the learning process is to help learners develop a reflective attitude towards their learning. This can be done by embedding self-assessment and self-evaluation activities into materials. The ideas and principles discussed so far can be molded into pedagogical materials in a number of ways. Below is a basic procedure that I follow in creating task-based materials.

\section{Step 1: Select a target / real world task}

The first step in designing a module of work is to select a target task from the inventory that you have already created. This represents what the learner should be able to do after working through the module of work. It is a good idea to state target task as a performance objective at the beginning of the module. For example, 'At the end of this module, you should be able to give directions to a fellow student on how to get from the school to your home.' 
Step 2: Create a schema building (pedagogical: activation) task

In materials based on an analytical approach to language learning, students are presented with "chunks" of language rather than with sample sentences or utterances containing the "structure of the day". In order to help them deal with heterogeneity, the module should begin with a schema building task. (Schemata are mental frameworks that we use to help us function in our daily lives. We have 'restaurant' schemata that help us when we go out to eat, and 'cinema' schemata that guide us through the process of going to the movies.)

A schema building task can be as simple as getting students to match a list of vocabulary items to pictures of those items. Alternatively, they could be asked to brainstorm and come up with a list of the expressions and phrases that they already know in relation to a particular topic or issue. This 'scene setting' work will introduce the topic, set the content for the module, present some of the language that they will encounter, and remind them of what they already know of the topic at hand.

\section{Step 3: Controlled practice (enabling exercise)}

The next step is to give students controlled practice of the key language structures, vocabulary and functions that they will need in order to carry out the target task. Audiolingualism provided controlled practice through decontextualised pattern drills such as the following:

Teacher: This is a pen - book.

Students: This a book.

Teacher: These. 
Students: These are books.

Teacher: Pencils.

Students: These are pencils.

Teacher: This.

Students: This is a pencil.

(etc.)

Intensive repetition of target language items can be carried out within a more meaningful context through exercises such as the following.

1. Practice the model sentence:

A: I don't feel well.

B: What's up?

A: I have a terrible headache.

B: Really? Maybe you should take some aspirin.

A: OK, I will

2. Match the problem and the advice.

\begin{tabular}{|ll|}
\hline & \\
take some aspirin & headache \\
drink a lot of juice & stuffy nose \\
go home and rest & stomach ache \\
drink some hot tea & fever \\
take some medicine & cough \\
go and see a doctor & sore throat \\
\hline
\end{tabular}

3. Now practice the conversation again using the problems and advice in the box.

Step 4: Create authentic listening (rehearsal or activation) task

This step provides learners with intensive listening practice, ideally using authentic listening texts, or texts that simulate authentic listening (Helgesen \& Brown, 2003). This exposure provides learners with input and also with models of 
target language use. If you have recorded native speakers carrying out the target task, then you will have a ready-made source of data for this step. 
Step 5: Focus on form (enabling exercise)

At this point, it is time for learners to focus on form. The focus can be on some aspect of pronunciation, grammar, or both. They might listen again to the authentic conversations from Step 4 and note aspects of stress, rhythm or intonation, or they could complete an inductive exercise requiring them to notice some aspect of grammar such as adverb placement. The rationale for introducing focus on form exercises at this point in the pedagogical cycle rather than at the beginning is that it will be easier for learners to see the relationship between form and function. They have already practiced the forms in context, and they have been listening to native speakers using the form communicatively. Now it is their opportunity to examine and manipulate the linguistic forms.

Step 6: Provide opportunities for freer practice through communicative activities or activation tasks

Until this point in the cycle, learners have been involved in 'reproductive' language work. That is, they have been reproducing and manipulating language models provided within the materials. It is now time for them to engage in more creative language work, where they have to use the language they have been practicing in less constrained ways through role plays, information gaps, and so on.

Step 7: Create a rehearsal task that mirrors the target / real world task

The next step is for the students to simulate the target task. If the material and practice opportunities presented to students in the preceding steps have been 
carefully developed with the pedagogical task in mind, this step should be relatively unproblematic for students.

Step 8: Focus on the learning process

The final step is to get learners to reflect on the instructional cycle, and to review the language that they have learned and practiced. This step can involve them in making a record of the language they have learned or completing a self-evaluation of how well they think they have done. When the steps are put together into a pedagogical sequence, they look like the sequence set out in the following table:

\section{Table 1: A pedagogical sequence for introducing tasks}

\begin{tabular}{|c|c|}
\hline Step & Example \\
\hline $\begin{array}{l}\text { 1. Create a number of schema } \\
\text { building tasks that introduce } \\
\text { initial vocabulary, language } \\
\text { and context for the task. }\end{array}$ & $\begin{array}{l}\text { Look at newspaper advertisements for renting accommodation. } \\
\text { Identify key words (written as abbreviations), and match people } \\
\text { with accommodation. }\end{array}$ \\
\hline $\begin{array}{l}\text { 2. Give learners controlled } \\
\text { practice in the target } \\
\text { language vocabulary, } \\
\text { structures and functions. }\end{array}$ & $\begin{array}{l}\text { Listen to a model conversation between two people discussing } \\
\text { accommodation options and practice the conversation. } \\
\text { Practice again using information from the advertisements in step } \\
\text { 1. }\end{array}$ \\
\hline $\begin{array}{l}\text { 3. Give learners authentic } \\
\text { listening practice. }\end{array}$ & $\begin{array}{l}\text { Listen to several native speakers inquiring about accommodation } \\
\text { and match the conversations with newspaper ads. }\end{array}$ \\
\hline $\begin{array}{l}\text { 4. Focus learners on linguistic } \\
\text { elements - e.g. grammar } \\
\text { and vocabulary. }\end{array}$ & $\begin{array}{l}\text { Listen again to conversations and note intonation contours. } \\
\text { Use cue words to write complete questions and answers } \\
\text { involving comparatives (cheaper, closer, more spacious etc.) }\end{array}$ \\
\hline 5. Provide freer practice. & $\begin{array}{l}\text { Pair work information gap role play. Student A, play the part of a } \\
\text { potential tenant. Make a note of needs and then call rental agent. } \\
\text { Student B plays the part of a rental agent. Use ads., and offer } \\
\text { partner suitable accommodation. }\end{array}$ \\
\hline 6. Pedagogical task & $\begin{array}{l}\text { Group work discussion and decision making task. Look at a set of } \\
\text { advertisements and decide on the most suitable place to rent. }\end{array}$ \\
\hline 7. Learning focus & $\begin{array}{l}\text { Get students to list ten new words and two new grammar points. } \\
\text { Students review three learning goals and, on a three point scale, } \\
\text { evaluate how well they can perform these goals. }\end{array}$ \\
\hline
\end{tabular}

(Adapted from Nunan, 2004, pp. 34-35) 
This table exemplifies the development of a module based on the target task of deciding on the most suitable place to rent. The target or real world realization of this sequence would be for students to actually go out and rent an apartment, or investigate suitable apartments for rent outside of the classroom. In some contexts and situations this may actually be possible.

\section{Implementing a task-based approach}

The concept of task-based language teaching and learning has been around for over twenty years. However, it is only just beginning to gain traction in published materials. This is due largely to the inherent conservatism of the field, a conservatism perpetuated by an understandable timidity on the part of commercial publishers, and a lack of adequately / appropriately trained teachers in the field particularly in EFL as opposed to ESL settings.

For those of us who believe that TBLT offers an effective and viable approach to language pedagogy, it is important to promote principles as well as practice. If teachers and students do not understand the principles, then the practice will not be implemented in a way that will maximize its effectiveness. I have observed classes in which teachers have turned task-based materials into a grammartranslation lesson because that is all they know on how to do it. It is therefore vitally important that materials have a 'how to' dimension that provides education, development and support to teachers.

The major advantage of a task-based approach is that it represents a direct approach to language pedagogy. In other words, the ultimate purposes for learning 
the language in the first place form the point of departure for syllabus design and materials development. This can be crucial in helping to maintain the motivation of the learners, because they receive short term 'pay-off' for their efforts. In traditional approaches, pay-off for learner efforts may not become apparent for months or even years. In task based instruction, learners can often perform a realworld task at the end of a unit of work, or even at the end of a single lesson.

There are disadvantages of course. There is no doubt that task-based teaching requires greater classroom management skills and target language competence on the part of the teacher than more traditional approaches. The approach can also be confusing to learners who have been raised in traditional grammar-translation or grammar driven classrooms. It is for this reason, that learner training is an important aspect of task-based language teaching. (For a rationale and exemplification see Nunan, 1999).

\section{Conclusion}

In this chapter, I have described the principles and procedures underpinning taskbased language teaching. In the first section of the chapter, I differentiated between synthetic and analytical approaches to pedagogy, and defined key concepts relating to TBLT. I then described and exemplified one procedure for designing task-based materials. In the final section of the chapter, I discussed key questions that currently preoccupy materials designers, and related these to TBLT.

In the final section of the chapter, I outlined some of the challenges and impediments to implementing task-based pedagogy. These impediments are not to 
be taken lightly. TBLT has had a struggle to gain traction in curriculum development and materials design because of the inherently conservative nature of the educational enterprise, particularly in EFL settings. Many teachers who have themselves learned foreign languages in such settings tend to teach the way they were taught, which is almost invariably through synthetic approaches and find it difficult to understand and implement approaches based on an analytical view of language learning. 


\section{Questions and tasks}

1. Think about your own teaching situation, or a situation with which you are familiar, and identify the major impediments to the introduction of a task-based approach.

2. Think of one major advantage and one major disadvantage of synthetic and analytical approaches to syllabus design and complete the following table:

\begin{tabular}{|l|l|l|}
\hline & Advantage & Disadvantage \\
\hline Synthetic & & \\
\hline Analytic & & \\
\hline
\end{tabular}

3. Think of some strategies that you might use to convince teachers and students from traditional learning backgrounds of the benefits of adopting a task-based approach.

4. Create a pedagogical task based on the following real-world task.

Look through the 'cars for sale' section of the classified advertisements of your local newspaper or a website and select three cars to inspect based on price and suitability for your needs.

5. Select a textbook with which you are familiar. Evaluate / adapt one unit or lesson using the evaluation questions set out in Appendix A to this chapter. (Note: Not all questions will necessarily be relevant.)

6. Modify / adapt one unit or lesson, based on the evaluation you carried in task 5, above incorporating the ideas / suggestions presented in this chapter to make it more 'task-based'.

7. Review the pedagogical sequence for introducing tasks, and then design your own module using the table below:

\begin{tabular}{|l|l|}
\hline Step 1 & Example \\
\hline $\begin{array}{l}\text { Create a number of schema building tasks that } \\
\text { introduce initial vocabulary, language and } \\
\text { context for the task. }\end{array}$ & \\
\hline Step 2 & Example \\
\hline $\begin{array}{l}\text { Give learners controlled practice in the target } \\
\text { language vocabulary, structures and functions. }\end{array}$ & \\
\hline Step 3 & Example \\
\hline Give learners authentic listening practice. & \\
\hline Step 4 & Example \\
\hline $\begin{array}{l}\text { Focus learners on linguistic elements - e.g. } \\
\text { grammar and vocabulary }\end{array}$ & \\
\hline Step 5 & Example \\
\hline Provide freer practice. & \\
\hline Step 6 & Example \\
\hline Pedagogical task & \\
\hline Step 7 & Example \\
\hline Learning focus & \\
\hline
\end{tabular}

(Adapted from Nunan 2004, pp. 34-35) 


\section{References}

Anderson, N. (2006). Active Skills for Reading. Second Edition. Boston: Thomson Learning / Heinle.

Asher, J. (1988). Learning another Language Through Actions: The Complete Teacher's Guidebook. Los Gatos CA: Sky Oaks Productions.

Bygate, M., Skehan, P., \& Swain, M. (2001). Researching Pedagogic Tasks: Second Language Learning, Teaching and Testing. London: Longman.

Doughty, C. \& Williams, J. (eds.) (1998). Focus on Form in Classroom Second Language Acquisition. Cambridge: Cambridge University Press.

Ellis, R. (2003). Task-Based Language Teaching and Learning. Oxford: Oxford University Press. Heinemann International Guide for Writers. (1991). Oxford: Heinemann.

Helgesen, M. \& Brown, S. (2003). Listening. In D. Nunan (ed.) Practical English Language Teaching. New York: McGraw Hill.

Krashen, S. (1981). Second Language Acquisition and Second Language Learning. Oxford: Pergamon.

Krashen, S. (1982), Principles and Practice in Second Language Acquisition. Oxford: Pergamon. Littlewood, W. (1981). Communicative Language Teaching: An Introduction. Cambridge: Cambridge University Press.

Long, M.H. (1985). A role for instruction in second language acquisition. In K. Hyltenstam \& M. Pienemann (eds.) Modelling and Assessing Second Language Acquisition. Clevedon Avon: Multilingual Matters.

Nunan, D. (1999). Second Language Teaching and Learning. Boston: Thomson Learning / Heinle.

Nunan, D. (2001). Expressions: Meaningful English Communication. Boston: Thomson Learning / Heinle.

Nunan, D. (2003). Listen In. Second Edition. Boston: Thomson Learning / Heinle.

Nunan, D. (2004). Task-based Language Teaching. Cambridge: Cambridge University Press.

Nunan, D. (2007). What is This Thing Called Language? London: Palgrave/ Macmillan.

Richards, J.C. (1986). Publish or perish. Paper presented at the Annual TESOL Convention, Anaheim, California, March 1986.

Richards, J.C., J. Platt \& H. Weber. (1986). Longman Dictionary of Applied Linguistics. London: Longman.

Scarcella, R. \& R. Oxford. (1992). The Tapestry of Language Learning: The Individual in the Communicative Classroom. Boston: Heinle \& Heinle.

Skehan, P. (1998). A Cognitive Approach to Language Learning. Oxford: Oxford University Press. 
Swain, M. (1985). Communicative competence: Some roles of comprehensible input and comprehensible output in its development. In S. Gass \& C. Madden (eds.) Input in Second Language Acquisition. Rowley Mass.: Newbury House.

Thornbury, S. (2000). How to Teach Grammar? London: Pearson ESL.

Tomlinson, B. (2001). Materials development. In Carter, R. \& D. Nunan (eds.) The Cambridge Guide to Teaching English to Speakers of Other Languages. Cambridge: Cambridge University Press.

Ur, P. (1988). Grammar Practice Activities: A Practical Guide. Cambridge: Cambridge University Press.

Wilkins, D. (1976). Notional Syllabuses. Oxford: Oxford University Press.

Willis, J. (1996). A Framework for Task-Based Learning. London: Longman.

Willis, D. \& Willis, J. (2001). Task-based language learning. In R. Carter \& D. Nunan (eds.) The Cambridge Guide to Teaching English to Speakers of Other Languages. Cambridge: Cambridge University Press. 


\section{Appendix A: Checklist for evaluating communicative tasks}

Goals and rationale

- To what extent is the goal or goals of the task obvious a) to you b) to your students?

- Is the task appropriate to the learners' proficiency level?

- To what extent does the task reflect a real-world or pedagogic rationale? Is this appropriate?

- Does the task encourage learners to apply classroom learning to the real world?

- What beliefs about the nature of language and learning are inherent in the task?

- Is the task likely to be interesting and motivating to the students?

Input

- What form does the input take?

- Is it authentic?

- If not, is it appropriate to the goal of the task?

Procedures

- Are the procedures appropriate to the communicative goals of the task?

- If not, can they be modified to make them more appropriate?

- Is the task designed to stimulate students to use bottom-up or top-town processing skills?

- Is there an information gap or problem which might prompt a negotiation of meaning?

- Are the procedures appropriate to the input data?

- Are the procedures designed in a way which will allow learners to communicate and cooperate in groups?

- Is there a learning strategies dimension, and is this made explicit to the learners?

- Is there a focus on form aspect, and if so, how is this realized?

\section{Roles and settings}

- What learner and teacher roles are inherent in the task?

- Are they appropriate?

- What levels of complexity are there in the classroom organization implicit in the task?

- Is the setting confined to the classroom?

\section{Implementation}

- Does the task actually engage the learners' interests? 
- Do the procedures prompt genuine communicative interaction among students?

- To what extent are learners encouraged to negotiate meaning?

- Does anything unexpected occur as the task is being carried out?

- What type of language is actually stimulated by the tasks?

- Is this different from what might have been predicted?

\section{Grading and integration}

- Is the task at the appropriate level of difficulty for the students?

- If not, is there any way in which the task might be modified in order to make it either easier or more challenging?

- Is the task so structured that it can be undertaken at different levels of difficulty?

- What are the principles upon which the tasks are sequenced?

- Do tasks exhibit the 'task continuity' principle?

- Are a range of macroskills integrated into the sequence of tasks?

- If not, can you think of ways in which they might be integrated?

- At the level of the unit or lesson, are communicative tasks integrated with other activities and exercises designed to provide learners with mastery of the linguistic system?

- If not, are there ways in which such activities might be introduced?

- Do the tasks incorporate exercises in learning-how-to-learn?

- If not, are there ways in which such exercises might be introduced?

\section{Assessment and evaluation}

- What means exist for the teacher to determine how successfully the learners have performed?

- Does the task have built into it some means whereby learners might judge how well they had performed?

- Is the task realistic in terms of the resources and teacher-expertise it demands?

(Adapted from Nunan, 2004) 